\title{
Employees as Corporate Stakeholders
}

Poonam Puri

Osgoode Hall Law School of York University, ppuri@osgoode.yorku.ca

Tuvia Borok

Source Publication:

Journal of Corporate Citizenship. Volume 8 (2002), p. 49-61.

Follow this and additional works at: https://digitalcommons.osgoode.yorku.ca/scholarly_works c) (i) $\Theta \Theta$

This work is licensed under a Creative Commons Attribution-Noncommercial-No Derivative Works 4.0 License.

Recommended Citation

Puri, Poonam, and Tuvia Borok. "Employees as Corporate Stakeholders." Journal of Corporate Citizenship 8 (2002): 49-61.

This Article is brought to you for free and open access by the Faculty Scholarship at Osgoode Digital Commons. It has been accepted for inclusion in Articles \& Book Chapters by an authorized administrator of Osgoode Digital Commons. 


\title{
Employees as \\ Corporate Stakeholders
}

\author{
Poonam Puri and Tuvia Borok \\ Osgoode Hall Law School, York University, Canada
}

Enron offers a prime case study to explore the many failures of the modern corporation to treat its employees even-handedly, ethically and with respect. Employees make significant personal investments into the corporations they work for, but employee interests are rarely of concern to directors.

This paper analyses several theories on the nature and purpose of the corporation and argues that the interests of stakeholders other than shareholders ought to be legally recognised in the corporation. The paper examines three theories on employees and employment, and argues that the human capital theory is most meaningful and best reflects the role of the employee when that employee is analysed in a broad social, political and economic context.

The authors evaluate reforms, such as stakeholder statutes, which have been implemented in various jurisdictions, and set out specific amendments that ought to be implemented to recognise the status of the employee as an important corporate stakeholder in the modern corporation.

\footnotetext{
Corporate law

Corporate governance

Employees

Stakeholders

Shareholder primacy

Stakeholder remedies
}

Poonam Puri is an Associate Professor of Law at Osgoode Hall Law School, York University in Toronto, Canada. Her primary areas of research and teaching are corporate law, corporate governance, corporate crime, securities law, bankruptcy law, the legal profession and the economics of legal fees. Her most recent publications have appeared in The Cornell Law Review, The

Georgetown Journal of Legal Ethics and The Osgoode Hall Law Journal.

Tuvia Borok is a graduating law student of Osgoode Hall Law School in Toronto, Canada. This autumn, Tuvia will pursue his master's of law abroad focusing on the study of global corporate markets. He is scheduled to return to the firm of Osler, Hoskin \& Harcourt in Toronto, Canada, after his graduate studies.
Osgoode Hall Law School, York University, 4700 Keele Street, Toronto, Ontario, Canada, $\mathrm{M}_{3} \mathrm{IP}_{3}$ ppuri@yorku.ca www.osgoode.yorku.ca

Osgoode Hall Law School, York University, 4700 Keele Street, Toronto, Ontario, Canada, M3) $1 \mathrm{P}_{3}$ tborok@osgoode.yorku.ca 
HOSE INTERESTS MUST BE RESPECTED AND HONOURED IN THE DELIBERATION of corporate actions? Which stakeholders have a legitimate claim on the corporation? Market changes and competitive pressures have forced companies to pursue strategies such as mergers, acquisitions, takeovers, restructuring and downsizing. However, these corporate tactics often fail and far too often result in bankruptcy. The rise and fall of Enron is an unfortunate, but principal, example. Enron was formed in a merger 15 years ago between two old-line natural gas pipeline companies. The company did not conduct a traditional 'bricks-and-mortar' business. It sold itself as a 'new-economy' company. It developed sophisticated financial trading technologies and made use of derivatives as a specialised financial instrument.

Enron's corporate tactics ranked it as the seventh largest company in the USA in 2000 , with reported sales of US\$I billion. In fact, the press consistently presented the corporation as having the most extraordinary managers in the corporate market. Yet, despite its successful and rapid growth, Enron also represented the largest bankruptcy in US history. Several thousand employees lost their jobs immediately, and the remaining few thousand have now also lost their jobs. The perceived splendour of Enron and its management has dissipated. Approximately 20,000 employees lost most of their retirement savings because the company had encouraged them to purchase Enron stock for their $40 \mathrm{I}(\mathrm{k})$ retirement plans. Employee claims in the bankruptcy rank behind many other Enron creditors, and US\$400 million remains owing to senior staff who will in all probability recover only a fraction of their wages.

Enron's actions for growth and success were driven by the desire for shareholder wealth, as is the case with most large corporations. In fact, both corporate law statutes (see e.g. Canadian Business Corporations Act I985: s.I22[I]) and case law in most common law jurisdictions ${ }^{1}$ support the directors' emphasis on shareholder interests. This approach has served to benefit shareholders of publicly traded corporations but has neglected to consider the inequities that arise for other stakeholder groups such as creditors, customers, suppliers, local communities and, especially, employees.

Our focus in this paper is on employees. The legal status of employees under corporate law statutes in Canada and most other common law jurisdictions is shameful. Employees are often not treated even-handedly, ethically or with respect because corporate decision-making focuses almost exclusively on shareholder value. Corporations that engage in short-term thinking and cost-cutting measures to the detriment of employees are ultimately hurting themselves. Employees are an important corporate stakeholder group in the modern corporation. In this paper we make the case for employees as primary corporate stakeholders whose interests ought to be considered by directors on a par with shareholder interests. To this end, we propose a statutory provision that ought to be included in corporate law statutes that expressly authorises directors to consider employee interests together with shareholder interests.

Although in this paper we use Canadian and Us corporate law for discussion, our analysis and proposals for reform are worth consideration by other common law jurisdictions that are similarly situated. An analysis and understanding of Canadian and US corporate law on this issue is also important given the continued globalisation of business and the elevated power and clout of North American organisations on the global market. North American parent corporations are increasingly imposing their corporate strategies and vision on subsidiaries and affiliates worldwide. Ultimately, actions taken by North American corporations or laws that they must follow will create a domino effect that will impact other foreign corporations and the conduct of business internationally.

1 Courts have equated 'acting in the best interests of the corporation' with acting in the best interests of the shareholders; see Dodge v. Ford Motor Company, I70 N.W. 668 [19I9]. 
Following this introduction, we set out three competing theories on corporate governance and stakeholders: the traditional (shareholder primacy) theory, the progressive (stakeholder) theory, and the human capital theory. We conclude that the human capital theory is superior: that employees are investors of human capital with corporate expectations equivalent to those of shareholders who are investors of financial capital. We also advance the position that employees are more vulnerable than shareholders on the basis that, unlike shareholders who may invest in multiple corporations, employees are unable to diversify their investments as effectively. We also justify our focus on employees and why we do not include other stakeholders in our analysis or proposals for reform. In comparison with other stakeholder groups, such as customers and suppliers, employees are more permanently tied to their employer corporation and are not as free to shift their relationships to other corporations. Customers and suppliers generally have more choice to enter into transactions with a number of businesses. In our view, the vulnerable and disadvantaged status of employees ranks them ahead of other stakeholder groups and on a par with shareholders. We build on the human capital theory to advance our argument in favour of requiring directors to consider employee interests in corporate decision-making.

We then go on to analyse the legal status of employees under corporate law and make the case that existing legal protection is insufficient. This is followed by an examination of the success and criticism of US constituency statutes that allow directors to consider non-shareholder interests in corporate decision-making. We analyse the critique that constituency statutes make managers accountable to everyone in theory but no one in practice. Accordingly, we cite US stakeholder statutes and build only on their strengths in developing an employee-centred statutory provision. In the penultimate section we introduce our model of an employee-focused stakeholder statute and explore the implications of our solution. In the final section we present our conclusions.

\section{Competing theories of corporate governance and stakeholders}

How one conceptualises the term 'corporation' greatly affects the meaning of acting in the 'best interests of' a corporation. In this section we analyse three competing theories of corporate governance and consider the legitimacy of the interests of non-shareholder stakeholders under each of them. We advance the position that the human capital theory provides the best theoretical foundation on which the interests of employees ought to be considered on a par with the interests of shareholders.

\section{Traditional corporate law theory: shareholder primacy}

Traditional corporate law theory is based on the view that shareholders are of primary importance with respect to corporate decision-making. Under Canadian corporate law statutes, directors owe a duty to act in the best interests of the corporation (CBCA I985: note I, S.I22[I][a]) interpreted by courts as a duty to maximise economic value for shareholders (see Dodge v. Ford Motor Company [I9I9]: note I). In Parke v. Daily News [I962]: Ch. 927), the court held that the directors breached their fiduciary duties when they conferred a benefit on the company's employees, to the financial detriment of its shareholders (Parke v. Daily News [1962]: Ch. 963). The dicta of the case law is clear: directors must maximise profits for the benefit of the shareholders, while the interests of other stakeholder groups are to be protected through bargaining and contract law.

Four key premises underlie the reasoning justifying the shareholder primacy model (Leblanc i997): 
Shareholders own the corporation.

Other stakeholders can form contracts for their protection.

Directors are agents of the corporation.

- A fiduciary duty is owed exclusively to shareholders.

On closer examination, these premises are flawed. On the first premise, it is too farreaching to assume that shareholders own the corporation. From an economical perspective, shareholders are the financial backbone of a corporation, but from a property law outlook they have no ongoing legal ownership rights in the assets of a corporation. Share ownership simply entitles shareholders to a bundle of rights that may include voting and dividend rights, and rights on liquidation. Ownership of shares cannot stand as a justification for a shareholder primacy model.

On the second premise, it is difficult to accept as a blanket statement that non-shareholder stakeholders can sufficiently protect themselves through bargaining and contract. Non-shareholder stakeholders-particularly employees-may not have the bargaining power or ability to contractually protect themselves. Even labour organisations, which provide a collective employee voice, are often of little assistance to employees in overcoming bargaining power disparity with respect to job security. Issues of job security are often not up for negotiation in union negotiations because they are viewed as unduly restricting management decision-making discretion.

Shareholders rightly require statutory protection: they make large financial investments, they do not exercise control over their capital contribution to the corporation and they remain vulnerable to self-dealing by management. However, in comparison with other stakeholder groups, shareholders rank low in terms of vulnerability and need for protection.

\section{Progressive corporate law theory: consideration of stakeholders}

Proponents of stakeholder theory view the corporation as a complex set of intricate relationships and acknowledge the interests of multiple parties as integral to the successful functioning of a company. Stakeholder theory envisions the corporation as a network of integral components, including stakeholder groups such as employees, creditors and suppliers along with shareholders. A stakeholder is broadly seen as anyone who affects or is affected by a corporation (Springer I999).

The stakeholder-centred approach acknowledges that board decisions have implications that are more far-reaching than share value. The theory demands that corporations be managed in the interests of all stakeholders. With respect to consideration of employee interests under this theory, Adams and Matheson (2000) note that employees are as much members of a firm as shareholders who provide capital investment:

employees may have a much greater investment in the enterprise by their years of service, may have less ability to withdraw and may have a greater stake in the future of the enterprise than many of the stockholders (Adams and Matheson 2000: I,085).

The importance of the employee as a corporate stakeholder will be further developed later, in the reconsideration of the worker as an investor of human capital.

\section{Human capital and investment theories: new considerations}

Human capital is a combination of physical capability, intelligence and educational investment (Asefa and Huang I994). The term acknowledges that employees are more than machines: they provide ingenuity, creativity and initiative. Employees are human 
capital owners and investors. The currency that they bring to work consists of their abilities, behaviour, personal energy and time.

Conceiving of workers as investors rather than assets emphasises the link between employees and firms - '[the binding agent] between people and organisations derives from the ability and willingness of each to provide benefits to the other' (Davenport I999: 8; see also Hart and Moutos I995). Companies cannot live by numbers alone; they are dependent on their robust cultures. Commenting on the success of their corporations, many chief executive officers (CEOS) cite the importance of their workers as key to the firm's prosperity. The following comments by CEOs, quoted by Deal and Kennedy (I999: 22), illustrate this:

Starbucks CEO, Howard Schultz: 'If people relate to the company they work for, if they form an emotional tie to it and buy into its dreams, they will pour their hearts into making it better.'

Continental Airlines CEO, Gordon Bethune: 'Whatever problems you run into in running a business, they are all people problems . . . businesses are run by people. So at the root of whatever problems you have in your business, you'll find people . . . a lot of managers and executives miss the forest for the trees by forgetting to look at their people.'

Southwest Airlines CEO, Herb Kelleher: 'Culture is one of the most precious things a company has, so you must work harder on it than anything else.'

A corporation will not prosper if it assumes that it will be successful without the benefit of dedicated employees who believe in the company and want to make it succeed. Management ought to see employees as 'human capital owners willing, under the right circumstances, to contribute to an organisation's prosperity' (Deal and Kennedy I999: 22). With more mobile human capital markets, employees as investors will more readily shift their investment to a firm that will, ultimately, give them a better return.

In this capacity, employees are no different from shareholders. Both parties want to see the firm's wealth mature, and both want to reap the benefits of their investment, financial or otherwise. Employees should be thought of as venture capitalists who are investing their own assets. Therefore, it is legitimate to accept Davenport's (I999: 8) position that employees can be viewed as 'particularly active one-member board of directors with ultimate responsibility for [their] individual investment and return results'.

\section{The legal status of employees under corporate law}

\section{Employee vulnerability}

Without an investment of human capital by employees, as described in the previous section, a corporation is unable to function effectively. Combined with shareholders' capital investments, employees' human capital investments form an interlocking basis on which a corporate pyramid may be built. Without either, a corporation simply will not succeed. Accepting the argument that workers and shareholders are the two most critical investors or stakeholders in a corporation, we propose that they ought to share an equal claim on the corporation.

As noted in the traditional shareholder-centred view in the previous section, one could argue that the interests of both sets of parties are protected in different capacities: through fiduciary and legal duties for shareholders, and via contract for workers. The reality, however, is not that simple. Private (or collective) bargaining does not sufficiently 
protect the interests of employees and, as investors, they are far more vulnerable than corporate shareholders. Employees are also more vulnerable than shareholders, who are in a position to diversify their investments and are not solely dependent on one venture for their sustained livelihood.

Should directors owe a duty only to shareholders or to shareholders and employees? Diversified shareholders prefer that management maximise profits, even at the risk of potential bankruptcy: little regard is paid to firm-specific and long-term goals that do not provide for a capital return. ${ }^{2}$ However, much less diversified investors such as employees prefer a different risk-return calculation; they would rather see more average returns as opposed to high risk and the possibility of high returns (Asefa and Huang I994). Acknowledging the obvious dichotomy in bargaining power, potential risk on investment returns and the motives behind how different investors (shareholder compared with employee) view the corporation, it is clear that employees have more to lose than corporate shareholders.

But why should employees be granted priority over other stakeholder groups, such as creditors, customers and suppliers? There are several significant differences that justify the distinction. First, employees are tied to their employers and are dependent on their jobs for their financial and social wellbeing, whereas customers and suppliers often have a number of options available to them. Customers often have more choice in purchasing a comparable product or service from a competitor and rarely will a supplier bind itself into an exclusive contract that prohibits it from supplying other businesses. Second, with respect to the issue of contracting for protection, large suppliers and creditors generally have access to legal resources and the educational experience to have contracts drafted that protect their interests. However, in the case of employees there is often a divergence in the bargaining power between themselves and the corporation, not fully overcome by collective union bargaining, as noted above.

In theory, we do not reject that non-employee stakeholders groups are affected by corporate decision-making, but it appears that non-employee stakeholder groups have options available to them that do not make them fundamentally dependent on a corporation to the degree that employees are. Also, it is our view that, from a practical and political level, it will be easier to lobby and convince legislatures to introduce protection for stakeholder groups one at a time. Accordingly, once employee interests are introduced into corporate law statutes, with time it will be possible to lobby to introduce broader statutory stakeholder protection.

In Canada, corporate law does not account for, or provide, proper remedies for employees to secure their interests. ${ }^{3}$ Although employees may attempt to raise a deriva-

2 Leblanc (I997: I00) proposes that: 'institutional shareholders, executive compensation plans, shareholder litigation, the market for corporate control and management produce corporate decisions based on short-term profits and their effects on share prices'.

3 Globally, Canada is far behind many other countries that have acknowledged the protection of employee interests. In the USA, corporate constituency statutes have been protecting employees, as stakeholders, since I983. In Germany and Japan, the role of the employee is acknowledged via systems that create a link between industrial relations and corporate governance, primarily through political cultures. David Charny (quoted in Blair and Roe I999: I05) notes that: 'The German model ... provides the basis for labour participation in managerial decision-making at three levels. Contracts regarding terms of compensation are negotiated industry-wide, with the social welfare state providing an important component of background compensation . . . in the form of welfare entitlement. At firms, workers' councils (abetted by relatively powerful unions) deal with plant-level enforcement of contract and legal rights and at least temper the exercise of managerial power in implementing investment decisions and determining production methods. At the top, co-determination enables the worker to have input at the high managerial level through representation on the supervisory board, and, perhaps even more important, it provides access to information about managerial decisions. The Japanese labour relations system, like the German system, enables workers to participate in strategic decision-making both at the shop floor and at the pinnacles of corporate management, but 
tive action or oppression claim against the corporation in their capacity as a minority shareholder or creditor, neither adequately accounts for the protection of employee interests.

\section{Employees as minority shareholders}

Employees may be granted shares in a corporation as part of a remuneration package, or they will purchase shares in their employer corporation, but this will rarely result in a majority shareholder status. A conflict may then arise between the interests of the financial shareholders (who constitute a majority and who may be seeking short-term profit maximisation) and employee shareholders (who are generally concerned with the long-term welfare of the corporation). Unfortunately, management will often act in the interests of majority shareholders, for obvious reasons. Accordingly, employees, as minority shareholders, may attempt to use the statutory derivative action to remedy corporate decisions that are not in the best interests of the corporation (for the provisions of the derivative action, see CBCA I985). ${ }^{4}$

The statutory derivative action allows a minority shareholder to claim that a board's actions were not in the best interests of the corporation:. When a corporation is aggrieved, a minority shareholder may, in turn, instigate an action to remedy the wrong. In the case of directors' actions that have a negative impact on employees, they may, if they are also shareholders, argue that considering only profit maximisation is a harm to the corporation because of potential negative long-term consequences. Any such claim would, obviously, be driven by employees' motives of ensuring the corporation prospers, develops and thus maintains employee jobs. However, if one accepts the human capital theory discussed in in the previous section, then ensuring that employees keep their jobs is a factor in the long-term growth, development and success of a corporation.

It is unclear why employees, without shareholding, are not deemed 'proper persons' for instituting a derivative action. ${ }^{5}$ Courts have acknowledged that (First Edmonton Place Ltd. v. 315888 Alberta Ltd. [1988]):

in addition to protecting minority shareholders, the actions provided for by [the derivative action and oppression remedy] serve the more general purpose of ensuring managerial accountability. That purpose encompasses protection of the rights of not only minority shareholders, but also creditors and even the public in general.

Therefore, although not a prevailing view in Canadian jurisprudence, employees ought to have a right to claim, on behalf of the corporation, that a wrong was committed to the firm if long-term employee interests were neglected in directors' corporate decisions and/or actions.

it does so largely through informal, non-legal mechanisms. Japanese industrial production methodswith their emphasis on flexible work teams, job rotations and problem solving and resource allocation at the shop floor level_-inherently require workers to make strategic decisions as part of the ongoing production process. The Japanese model allows for promotion and 'working up the ranks' that ensures that at least some board members will have personal connections and familiarity with the firm, having invested their human capital over their careers with the corporation.'

4 Prior to the enactment of the statutory derivative action provisions, the harsh common law rule in Foss v. Harbottle [1849], 67 E.R. I89 denied minority shareholders a remedy against abusive actions by majority shareholders that were not in the best interests of the corporation. For an analysis of the statutory derivative action, see First Edmonton Place Ltd v. 3I5888 Alberta Ltd [I988] A.J. No. 5II.

5 Traditionally, the courts have restricted the derivative action to shareholders. However, some courts have considered and upheld that the remedy could be extended to creditors as well; see Bank of Montreal v. Dome Petroleum [I987], 54 Alta. L.R. (2d) 289. 
Alternatively, employees may elect to bring an action in their capacity as minority shareholders under the statutorily provided oppression remedy (for the statutory provisions of the oppression remedy, see CBCA I985). The broadness of the wording of this remedy would, potentially, allow employees to commence an action in their own personal capacity (without shareholding) although no such claim has been grounded in any Canadian judgement. Accordingly, an employee currently has to be cloaked as a minority shareholder complainant, or perhaps even as a creditor complainant. In determining whether relief should be granted, the courts have focused on: the reasonable expectations of the stakeholder; the unfairness or prejudice of the conduct in light of these expectations; and the impact of the conduct on the stakeholder's interests.

Without statutory guidance in determining 'reasonable expectations' and 'unfairness' courts have made use of their broad discretion in examining each case on its merits. Among other conduct, courts have held as reasonable shareholders' expectations that the business will not fail and will not liquidate (see Westfair Foods Ltd v. Watt [I998]). One may propose that this expectation, that the business will not fail, may be extended to the employee context. After all, employees do not want to see the collapse of their employer firm, because they are dependent on such employment to sustain financial viability. In Westfair Foods Ltd v. Watt [I998], the Ontario Court of Appeal held that directors have a duty of prudent management to forestall the failing and liquidation of a business. Perhaps this line of reasoning could be used for employees to obtain future relief under the oppression remedy.

\section{Employee as creditor}

Should employees be given 'complainant' status for statutory corporate law remedies on the basis that they are creditors of the corporation? The court in Trillium Computer Resources Inc. v. Taiwan Connection Inc. [I992] noted that 'the use of the oppression remedy by creditors is one aspect of the oppression remedy which is likely to see increased activity and considerable development in the future'. Some judges have, however, held that complainant status to creditors should not be granted freely (Royal Trust Corp. of Canada v. Hordo [1993]):
the court's discretion should not be used to give 'complainant' status to a creditor where the creditor's interest in the affairs of a corporation is too remote or where the complaints of a creditor have nothing to do with the circumstances giving rise to the debt or if the creditor is not proceeding in good faith. Status as a complainant should also be refused where the creditor is not in a position analogous to that of the minority shareholder and has no particular 'legitimate interest' in the manner in which the affairs of the company are managed.

The reasoning of the court in Royal Trust Corp. of Canada v. Hordo poses more questions than it provides answers: How is the position of a creditor to be likened to that of a minority shareholder? How does one define interests in the corporation as 'too remote?' And what constitutes 'legitimate interest' in a company's affairs?

One struggles with whether one applies progressive or traditional notions of corporate governance and corporate law theory in answering such questions. Traditional Canadian and US theory will eliminate many stakeholders from being granted complainant status even though the broad nature of the legislation contemplates providing a remedy to aggrieved parties that may otherwise have no grounds for relief. Progressive stakeholder theorists would give a broader interpretation, and would extend complainant status to creditors more readily, and to employees as well.

Ultimately, the employee-corporation relationship mirrors the creditor-corporation relationship. Each invests, and each expects a return. Employees invest their human 
capital and expect more than short-term financial remuneration. They demand stability and recognition for their commitment. The employee-employer relationship is a voluntary commitment, and, in assessing the reasonable expectations of the parties, one looks not only to the written contract but also to the conduct and actions of the parties over the course of the relationship (Westfair Foods Ltd v. Watt [I998]).

Unless terms of employment specifically stipulate temporary tenure, it is rational to assume that any reasonable worker expects permanent employment (financial markets permitting). Therefore, if the company dismisses staff, it is proper to expect the employee to wish to seek remedy. This is not to say that any corporate downsizing is grounds for remedy, but such a situation rather begs the question 'who is going to look after the interests of employees?'

If corporations will not take it on themselves to consider their employees' interests, and, although possible, courts do not appear to be prepared to extend existing corporate law rights to employees, then it is time for statutory direction and guidance in the consideration of employee welfare. The best solution for Canada (and as a model for corporations around the world) would be the adoption of an employee stakeholder statute-based on a modification of the constituency statutes currently in place in the USA.

\section{US constituency statutes}

Stakeholder statutes have been prominent in the USA since I983. Pennsylvania was the first State to adopt such a statute, and by the year 200032 states adopted some form of constituency statute. The effect of stakeholder statutes has been to allow boards and individual directors to consider the effects that corporate decisions would have on employees, suppliers, customers and other stakeholders when contemplating whether any action is in the best interests of the corporation.

Stakeholder statutes in the USA take different forms. In some States they are optional and may be included in the charter of the corporation if the business so chooses. In other states, corporations may opt out of the state's constituency statute (for further discussion, see Springer I999). Other variations include the breadth of factors directors may consider, the context in which non-shareholder interests may be considered, the corporate fiduciaries protected by the statute, the specific non-shareholders to be considered or protected, and the level of protection accorded to a board's decision.

US constituency statutes recognise that the corporation is a social entity that meets a number of social needs beyond those of its financial shareholders. US stakeholder statutes affirm a corporation's obligations to non-shareholder parties that are affected by corporate decision-making. Constituency statutes have not, however, been immune to criticism. A central defect of stakeholder statutes is that 'adopting a regime that recognises shareholders as merely one of many constituencies or stakeholders... eliminates much of the guidance for managerial decision-making. Under these reforms, executives would be free to manage corporations based on caprice or bias' (Schulze I997: I,6I2). Accordingly, we advance the position in this paper that Canada should adopt a modified version of US constituency statutes focused exclusively on employees.

\section{A model for an employee-centred stakeholder statute}

Building on earlier sections of this paper, in this section we develop a model for an employee-centred stakeholder statute. Such a statute would require directors to consider 
employee interests together with those of shareholders. The following addition to the statutory duty of care provision in corporate law statutes is proposed:

I(a) Best interests of the corporation. In considering the best interests of the corporation, the board of directors, committees of the board, individual directors and individual officers are required, in good faith, and without limitation, to deliberate on the short-term and long-term effects of corporate actions on:

- The corporation itself

- Shareholders as a collective entity and individually

- Employees as a collective entity and individually

I(b) In making such a determination, consideration must be made of the reasonable effects of a proposed corporate action and the reasonable expectations of shareholders and employees.

I(c) No single interest, expectation or effect shall rank as a dominant or controlling factor, but, rather, interests and expectations must be considered, without limitation, in tandem.

I(d) Consideration and attention to reasonable interests, expectations and effects will not violate the duty of care of a director, or board of directors, to shareholders, or a group of shareholders, or employees, or a group of employees, if the directors make a reasonable determination, after a careful and prudent evaluation.

The proposed statutory provisions offer directors guidance in specifying the parties to whom they owe a duty: that is, the corporation, shareholders (as an entity and individually) and employees (as an entity and individually). The employee-stakeholder statute requires that the reasonable effects (of corporate actions), interests (of shareholders and employees) and expectations (of shareholders and employees) be taken into consideration, with no one factor or group having dominance. 'Reasonable' does not mean 'plausible'. It is more restrictive and reduces the likelihood of a frivolous action on the basis of a remote interest, expectation or effect that was not considered by a board.

Directors will be required to perform a 'careful and prudent evaluation', which will alleviate concerns with directors acting hastily and neglecting due consideration of all affected parties and interests. Such a standard is not unreasonable and could be ascertained by a court without difficulty. The standard would mirror that of directors' duties with respect to takeover bids. Courts would evaluate the actions of directors subjectively by examining, among other factors, written records of deliberations, the time spent discussing a corporate action and the thoroughness and reasonableness of the effects, interests and expectations considered. Finally, the statutory provisions attempt to alleviate concerns that directors will face increased liability by shareholders or employees who are of the view that their interests have been disregarded. The statute allows directors to act in good faith in the best interests of the corporation without fear of repercussion.

The proposed legislation would extend obvious benefits to employees who have historically been neglected in corporate decision-making. However, the proposed legislation would come at a cost. Employees would be far more restricted from bringing an action for remedies under the derivative action or the oppression remedy. Shareholders' ability to seek a remedy would also be restricted because the bar for oppressive conduct would be raised. The derivative action, which currently receives less application, would become nearly obsolete. Traditionally an action used by minority shareholders, it would be difficult for any claimant to argue that the corporation was harmed, as corporate interests are one of the factors directors must heed credence to under our proposal. The oppression remedy could still be used if a shareholder or employee could prove that a 
board did not consider reasonable effects, interests or expectations in making a corporate decision and it resulted in oppression. ${ }^{6}$

The only hurdle that remains is the question of what becomes of other stakeholders that have previously made use of the oppression remedy-primarily creditors. Hypothetically, the status of creditors and their interests would not differ from their current ranking: creditor interests would generally remain far removed from the minds of directors. Creditors could, potentially, argue that, under the new proposed legislation, their interests should be considered under subsection $\mathrm{I}(\mathrm{a})$ of the proposed provision: the interests of 'the corporation itself' embody the interests of those with whom the corporation has dealings in order to remain operative. Such interpretation would open the floodgates to claims by any and all stakeholders. However, understanding the underlying intent of the employee-stakeholder statute should, hypothetically, lead judges to a restricted interpretation. Perhaps it would be appropriate to include the intentions of the legislation directly in the statute, as has been done in some US statutes. A proposed footnote or preamble to the introduced text of the legislation could read:

2 Interpretation. In enacting subsection I, the legislature intends to reaffirm certain corporate governance rules and principles, and to acknowledge the key interests of employees and shareholders in corporate decision-making. Subsection I should be interpreted accordingly. In taking or declining to take any action, or in making or declining to make any recommendation to the shareholders of the corporation with respect to any matter, a board of directors will fully weigh the factors outlined in subsection I and in the good faith exercise of their business judgement make a reasonable investigation paying attention to the welfare of employees and shareholders concurrently.

As a result, the employee-stakeholder statute would offer legislative guidance to directors as well as to the judiciary and would overcome a number of vagueness issues in defining 'acting in the best interests of the corporation'.

\section{Conclusions}

Any case study of the rise and fall of Enron would highlight that financial benefits to shareholders are sought at the expense of more vulnerable parties within the corporation. The traditional shareholder primacy model is unsympathetic to the realities facing modern business firms. No one stakeholder group ought to have sole claim on the corporation, because the corporation, properly conceived, is a network of integral stakeholder components. Accordingly, the best interests of the corporation should not be equated with the best interests of shareholders, as traditional corporate governance theory suggests. A number of stakeholder groups partake in the proper functioning of any business organisation. Therefore, a stakeholder-centred approach properly evaluates the interests of all affected corporate parties. However, such a holistic approach is flawed: directors are unable to manage a corporation effectively if they are accountable to all corporate stakeholders. The reality of such a concern led us to evaluate the needs of stakeholders and rank their priority.

In so doing, we focused on employees as human capital owners and investors. We argued that employees may be equated to one-member boards that, with mobile human

6 This complements the specific language of s.24I(2), grounds for oppression remedy, of the CBCA (I985), which considers whether the powers of directors were exercised in a manner 'that is oppressive or unfairly prejudicial to or that unfairly disregards the interests of shareholders and employees'. 
capital markets, elect to invest their skill, labour and expertise in a firm that will offer the greatest return. We argued that, in this capacity, employees are no different from corporate shareholders who provide financial investment. Without either financial or human capital, a corporation would not be able to function.

Financial investment is not enough: Enron's financial assets were not solely responsible for its success. Success was dependent on the skill and knowledge of employees that could nourish Enron's financial resources to create products and services that paved the way to the corporation's prosperity. Therefore, among corporate stakeholders, the status of employees must be elevated to outrank any other constituent group, as employees are the ground-workers without whom there would be no need for other stakeholders.

In this paper, we have advanced the position that interests of employees ought to rank equal with shareholders, on the basis of their vulnerability, their lack of bargaining power in the employee-corporation relationship and their lack of diversification in their investment in the corporation. Furthermore, we analysed existing case law that highlighted that statutory relief is not available to employees to the same degree that it is provided to shareholders. We therefore concluded that the duties of directors should not be limited to shareholders but rather should be extended to parties that are at greatest risk of loss in corporate action-employees. We also made the case for our focus on employees to the exclusion of other stakeholder groups.

The US has dealt with employee and stakeholder vulnerability generally through the introduction of constituency statutes. We acknowledged that these statutes are not without flaw and we therefore argue that Canadian corporate law statutes ought to adopt a hybrid between the shareholder-centred approach currently in use in Canada and the broad, open-ended constituency statutes relied on in the US. We proposed a model of an employee-stakeholder statute, which, as the proposed text indicates, addresses the needs of employees, shareholders and the corporation as a whole. It offers directors clear guidelines with respect to corporate decision-making and with how to properly ascertain what the phrase 'acting in the best interests of the corporation' means. The added duty on directors is offset by the expected beneficial outcome that will see boards taking a more holistic approach that will benefit shareholders, employees and the corporation as a whole. The proposed addition will nourish business decisions and will stabilise and strengthen the growth and development of successful, prosperous corporations. In turn, the newly proposed provisions could act as a model for corporations operating around the world in the global marketplace.

Employees have a special relationship with the corporation that entails both social and economic consequences. Unfortunately, this reality has been neglected by current Canadian statutory provisions which equate the 'best interests of the corporation' with the 'best interests of shareholders'. The unfortunate reality, as evidenced by the Enron crisis, is that such corporate governance may result in grave consequences for far too many innocent parties. The best means of ensuring directors' appreciation of the full consequences of their actions is through the expansion of directors' duties to look beyond corporate shareholders and to include the consideration of employee interests.

\section{References}

Adams, E.S., and J.H. Matheson (2000) 'A Statutory Model for Corporate Constituency Concerns', Emory Law Journal 49 (Autumn 2000): I,085-I,I35.

Asefa, S., and W.-C. Huang (eds.) (I994) Human Capital and Economic Development (Kalamazoo, MI: W.E. Upjohn Institute for Employment Research).

Bank of Montreal v. Dome Petroleum [I987] 54 Alta. L.R. (2d) 289. 
Blair, M.M., and M.J. Roe (eds.) (I999) Employees and Corporate Governance (Washington, DC: The Brookings Institution Press).

CBCA (Canadian Business Corporations Act) (1985) RSC I985, c.C-44, S.I22(I) (Ottawa, Canada: Government Printer).

Davenport, T.O. (I999) Human Capital: What Is It and Why People Invest It (San Francisco: Jossey-Bass).

Deal, T.E., and A.A. Kennedy (I999) The New Corporate Cultures (Cambridge, MA: Perseus Books).

Dodge v. Ford Motor Company [1919] I70 N.W. 668.

First Edmonton Place Ltd v. 315888 Alberta Ltd [1988] A.J. No. 5II.

Foss v. Harbottle [1843] 67 E.R. I89.

Hart, R.A., and T. Moutos (I995) Human Capital, Employment and Bargaining (Cambridge, UK: Cambridge University Press).

Leblanc, R. (I997) The Stakeholder Debate (LLM thesis; Toronto: York University).

Parke v Daily News Ltd [1962] Ch.927.

Royal Trust Corp. of Canada v. Hordo [I993] Io B.L.R. (2d) 86.

Schulze, R.J. (I997) 'Can this marriage be saved? Reconciling Progressivism with Profits in Corporate Governance Laws (Book Note)', Stanford Law Review 49 (July I997): I,607-83.

Springer, J.D. (1999) 'Corporate Constituency Statutes: Hollow Hopes and False Fears', Annual Survey of American Law I: 8-IoI.

Trillium Computer Resources Inc. v. Taiwan Connection Inc. [1992] Io O.R. (3d) 249.

Westfair Foods Ltd v. Watt [1998] S.C.C.A. No. 634. 